\title{
Index to Vol. 59 (1998)
}

\author{
Compiled by Kathy L. (Kit) Dusky
}

Aamout, David, retired, 380

Abell, Millicent "Penny", appt., 538

Abston, Deborah, "Only change is constant: three librar ians consider what their jobs will be like in five years" \& port., 602

"Academic community sets agenda to reclaim scholarly publishing, "Case, 655

"Academic librarians as scholars: publishing is your moral obligation," Newman, 19-20, comments, 152-53

Academic librarianship and redefining scholarship project, ACRL, 336

"Academic libraries: 1994 now available from NCES," 334

Academic or Research Librarian of the Year Award, 1998, $275 ; 1999,589$

"Academic or Research Librarian of the Year Award resolution," 584

Acquisitions (by author, subject, or title): Actors (Hope), 715; Adolescents (Indonesia), 536; African hist. (Grey) 206; Ai, Maeda (Japanese lit.), 715; Art hist. (Buschen, 39; Manning, Suida, 377); Art hist. educ. (Korzenik), 457; Asante Collective Biog. Proj. (Wilks), 377; Athletics coll. 376-77; Aurhors (Uris), 207; Authors, British (Burgess), 617; Batson, Ruth M. (Hist. of Women in Amer.), 39; Biographies (San Martín), 796; Blatz Brew ing Co. (breweries), 617; Breweries (Blatz), 617; Broadcasting, 376; Burgess, Anthony (authors, British), 617;

\section{Guide to index}

Fin.ING is word-by-word (ALA, 1968).

Abrrevianons: Standard abbreviations are used except in titles. Names of some organizations, ALA, ACRL, LC, etc., are also abbreviated and are alphabetized as if spelled out.

\section{Special abbreviations:}

$\begin{array}{ll}\text { appt. } & \text { appointment } \\ \text { f. } & \text { foundation } \\ \text { port. } & \text { portrait } \\ \text { prof. } & \text { profile } \\ \text { prog. } & \text { program }\end{array}$

SPECIAL usages: More than one reference per page is indicated in parentheses. Under the head ing "Acquisitions (by author, subject, or title)" parentheses may enclose donors' names (for subjects) or subjects (for named collections).
Buschen, John (art hist., Eur. hist., humanities), 39 Calif. (hist.), 536; Carberry, H. D. (Caribbean studies), 122; Caribbean studies (Carberry), 122; Cartoonists (Grey, Segar), 206-7; Children's lit. (Dennis, 617 \& photo.; Spinelli, 715); Choreographers (Lewitzky), 295; Collins, Arthur A. (Radio Co.), 536; Collins Radio Co. 536; Dancers (Lewitzky), 295; Dennis, Wesley (children's lit.), 617 (\& photo.); Dialogues (Galileo), 122; Dos Passos, John, 122; Duncan, David Douglas (Phorographers), 715; Editors (Joiner), 796; Eur. hist. (Buschen), 39; Galileo (Dialogues), 122; Godfrey, Arthur (radio, television), $294-95$ (photo., 295); Governors (Thornburgh), 295; Grey, Rex 13. (African hist.) 206; Hamilton, Lee (U.S. representatives), 457 Harriman, Pamela Digby Churchill (U.S. Ambassador), 894: Hawthorne, Nathaniel, 121-22; Hawthorne, Sophia Peabody, 121-22; Herriman, George (cartoonist), 206-7; Historical preseryation (Peterson), 536; Hist (Africa, 206; Calif., 536); Hist. of Women in Amer (Batson), 39; Hooks, Benjamin (Politics), 715; Hope, Boh (Actors), 715; Humanities (Buschen), 39; Indonesia (adolescents), 536; Japanese lit. (Ai), 715 Jaúregui, José María Huarte (Spanish Civil War), 894; Joiner, Ernest V. (editors), 796; Korzenik, Diana (Art hist educ.), 457; Lafayette coll, 122; Lathrop, Julian, 121-22; Lathrop, Rose Hawthorne, 121-22; Levinson, Harry (Psychology), 377 (\& photo); Lewitzky, Bella (dancers, choreographers), 295; Manning, Bertina Suidad (art hist.), 377, Mayor, Lubbock, Tex. (Rogers), 377; Mazzeo, Rosario (music, clarinets), 617: Meredith, William (poets), 536; Michener (James A.) Archives, 39; Music, clarinets (Mazzeo), 617; Muskoka Lakes Association, 796; Nat. Black Writers Conf., 715; Patton, George S. (WWI), 377; Peterson, Charles E. (Historicalpreservation), 536; Photographers (Duncan), 715; Photography (Smith), 715; Poets (Meredith), 536; Politics (Hooks), 715; Psychiatry (Wolpe), 796; Psychologists (Sarwono), 536; Psychology (Levinson), 377 ; Radio (Godfrey), 294-95; Revolutionary War, 122; Rogers, W. D. "Dub" (Mayor, Lubbock, Tex.), 377 ; Sabo, George (Slavic coll.), 894; San Francisco Academy of Comic Art coll., 206-7; San Martín, José, General (biographies), 796; Sarwono, Sarlito Wirawan (psychologists), 536; Segar, Elzie (Cartoonist), 206-7; The Sbepbeardes Calender (Spenser), 796 ( \& photo.); Slavic coll. (Sabo), 894; Smith (W. D.), Inc. (Photography), 715; SNET Coll., 295 (\& photo.); Spanish Civil War (Jaúregui), 894; Spenser, Edmund (The Shepheardes Calender), 796 (\& photo.); Spinelli, Jerry (children's lit), 715; "Star Trek" coll. (Wakefield), 457; Suida, William Emil (art hist.), 377; Television (Godfrey), 294-95;

\section{About the author}


Thirteen/WNET Arthur Godfrey Coll, 294-95; Thornlsurgh, Dick (Governors), 295; Tobolowsky, Hermine Dalkowitz (women's equality), 536; Trials (Westmoreland vs. CBSS), 207; Union Pacific Railroad, 536; U.S. Ambassador (Harriman), 894; U.S. representatives (Itamilton), 457; Uris, Leon (Author), 207 Ursuline Sisters of New Orleans, 457; Wakefield, Marie ("Star Trek" coll.), 457: Westmoreland vs. CIBS (Trials), 207: Wilks, Ivor (Asante Collective Bio. Proj.), 377; Wolpe, Joseph (psychiatry), 796; Women's equality (Tobolowsky), 536; WWI (Patton), 377

Acquisitions (by institution): Bentley Coll., 377; Bowling Green State U., 457; Cleveland State U., 122; Conn. Coll. 536; Cornell U., 536, 715; CUNY, 715; Emory U. 377; Folger Shakespeare Lib., 796 (\& photo.); Geo. Wash. U., 376; Gettysburg Coll., 715; I Harry Ransom Hum. Research Ctr., 715; Historic New Orleans Coll., 457; Huntington Lib. 457 ( \& photo.); Ind. U., 457; LC 715, 894; Northwestern U], 377; Ohio state U., 206-7; Radcliffe Col., 39; Radio Hist. Soc., 376; Stanford U. 121-22; Tex. A\&M U., 206, 894; Tex. Tech U., 207 376-77 (2), 536, 796; U. of Conn., 295 (\& photo.); U. of low: 536 ; U of Md., 294-95, 536; U. of Memphis, 715; U. of Nev., Reno, 894; U. of N.D., 377; U. of Northern Colo., 39: U. of Pittshurgh, 295; U. of Southern Callif., 295, 536, 796 (2); U. of Tex. (Arlington, 715: Austin, 207, 617); U. of Va., 122, 617; U. of Waterloo, 796; U. of Wis., 39; U. of Wis., Milwaukee 617; U. of 1ll., Chicago, 122; UC, Santa Cruz, 617; Wash U., St. Louis, 122

Adams, Karen, appt, 124

Adams, Nancy, news note, 618 ; photo., 278

"Address the ACRL Board," 879

Advanced Book Exchange, "Shop for out-of-print books on the Web," 832

"Africa News Online" \& logo, rev. of, 35

"Agricola" \& logo, rev. of, 710

Alexander, Adrian W, appt, 296 97; appt \& port, 538

Alford, Larry, news note, 716

Alfred U., "Making history live: how to get students interested in university archives" \& photos, 423-25

Allen, Luella, retired, 126

Allen, Nancy, rev. ("Africa News Online" \& logo), 35

Amato, Sara, "Internet reviews," 34-34, 117-18, 201-2, $288-89,371-73,452-53,528-29,611-12,709-10,789$ $90,890-91$

AAHE, "Provosts, libraries, and electronic information reports from AAHE and CNI," 420-22

ACS, "Two state systems subscribe to ACS Web journals," 653

"American Directory Assistance" \& logo, rev. of, 201

"American librarians visit Gaza strip: their libraries are improving, but they still have a long way to go" \& photo., Sharma, 27-28

ALA, Annual Conference, 1997, "Imagining the Learning Library' tape available, " 150

ALA, Annual Conference, 1998, "Apply for ACRL preconferences," 285; "ACRL explores values in Washington, D.C." \& photos., 569-75, 676-81, 685 "ACRL 1998 President's program videos available," 830-31; "ACRL preconferences in D.C.: learn more about advocacy, instruction, or special collections," 193-95; "ACRL programs and meetings, " [AC1]-AC16 "ACRL programs at the 1998 ALA annual conference," 440-41; "Date set for 'Learning to Teach' preconference," 75; "Learning to teach will be of fered in I).C.," 9: "Order Annual Conference audiocassettes," 574; "Participate in CLS 'Dynamic Staff swap-n-shop," 333-34

ALA, Annual Conference, 1999, "DLS/IS seeks poster sessions/presentations for 1999 program," 654-55; "Draft of ALA Intellectual Freedom statement on Web," 246 "Gordon appointed ALA executive," 5; "IS Think Tank In participants sought," 750-52
ALA, Midwinter Meeting, 1998, photo., 146

ALA, Midwinter Meeting, 1999, "ACRL discussion groups, 881; "ACRI. meetings in Philadelphia: a tentative schedule," 879-84; "Join the leadership discussion," 880: "Meet Wand and Wilson-the candidates for ACRL president," 883; "New in the ALA Archives" \& photo., 751; "The President's program: O'Donnell and Wheatleydynamic speakers you shouldn't miss," 838

ALA Graphics, poster, 70

Ameritech, "National Digital Library competition," 617 and the Thomson Science and Technology Group," 750

Anderson, Kristina L., rev. ("Healthfinder" \& logo), 528

Anderson, N. Douglas, appt. \& port., 42

"Apply by Jan. 8 for info literacy program," 831

"Apply for ACRL preconferences," 285

Appointments, 41-44, 124-26, 209-10, 296-98, 378-79, 459-61, 538-41, 618-20,716-19, 798-800, 896-98

Arafat, Yasir, photo., 27

"Are you qualified to serve on the accreditation team? Survey results of six accrediting agencies," Nelson, 269-72, comment, 436

Arne Nixon Center for the Study of Children's Literature, 3

Arp, Lori, "Named Dudley Instruction Librarian" \& port., 278-79

Arseneau, Marjo Dobbs, deceased, 126

"AAMES opens Web site," ACRL, 73

ACRL, AAMES, "Opens Wel, site," 73

ACRL Academic librarians bip and redefining scholasbip project, 336

ACRL, Academic or Research Librarian of the Year Award, 1998,$275 ; 1999,589$

ACRL, "Academic or Research Lilbrarian of the Year Award resolution," 584

ACRL, "And the winners are... : here are the official results of the 1998 elections," 437-39

ACRL, "Annual conference programs and preconferences," 1998,868

ACRL, Annual report, 1997-98, 853-77

ACRL, Audiovisual Committee, "From audiovisual to media resources, "358

ACRL, "Award nominations," 280

ACRL, Board of Directors, "Address the ACRL Board," 870

ACRL, Board of Directors, "Highlights," (June, 174-81, 207 ; Feb, 582-87)

ACRL, Board of Directors, 1997-98, photo., 584, correction, 851; photo. \& roster, 869; 1998-99, photo., 586

ACRL, Budget \& Finance Comm. Chair, "Financial report" \& port., 870-74

ACRL, "Build your leadership skills," 75

ACRL, "Chapter relations task force report," 585

ACRL, CLS, CLIP notes, \#26, 75

ACRL, CLS, "College library management video available from ACRL," 246-47; "Participate in CLS 'Dynamic Staff' swap-n-shop," 333-34

ACRL, CLS, Criteria for Promotion and Tenure in Aca. demic Libraries (CLIP note $\# 26$ ) published, 75

ACRL, "Council of Liaisons," 866

ACRL, "Directory of ACRL accreditation advisors," 242-43

ACRL, DLS, "Guidelines for distance learning library services," approved 1998, 689-94; "Section renamed Distance Learning Section," 485-86

ACRL, "DLS/IS seeks poster sessions/presentations for 1999 program," 654-55

ACRL, Docroral Dissertarion Fellowship, 1998, 460; 1999 589

ACRL, "Don't miss Dec. 1 award deadline," 753

ACRL, EIBSS, Distinguished Education and Behavioral Sciences Librarian Award, 1998, 277-78; 1999, 589

ACRL, ECLSS, "Section renamed Distance Learning Section," 485-86

ACRL, "Enter the 'Define ACRL' contest," 10

ACRL, Exec: Director, "Letter" \& port, 858-59 
ACRL, "Fatzer and Hardesty share plans for ACRL: he sure to vote in the election this spring!," 103-107

ACRL, Hugh C. Atkinson Memorial Award, 1998, 274, 276; 1999,589

ACRL, "Imagining the Learning Library' aape available," 150

ACRI., "Institute for Information Literacy Immersion '99 an invitation to apply," 782-83

ACRL, "Internet resource topics in CGRL neus," 865

ACRL, IS, "Date set for 'Learning to Teach' preconference," 75: "Learning to teach will be offered in I).C., "9; "Think Tank III participants sought," 750-52

ACRL, 1S, Innovation in Instruction Award, 1998, 278; 1999 589; Instruction Publication of the Year Award, 1999 589; Miriam Iudley Instruction Librarian Award, 1998, 278-79: 1999. 589

ACRL, "Join the leadership discussion," 880

ACRL, "Leadership institute," 861

ACRL, LPSS, Marta Lange/CQ Award, 1998, 279; 1999, 589

ACRL, Media Resources Committee, "From audiovisual to media resources," 358 ; "Guidelines for media resources in academic libraries: a draft," 357-65

ACRL, "Members assess ACRI. prior to the new millennium: results of the 1997 member survey," 442-46

ACRL, "Members running for ALA council: these ACRI members need your vote," 192

ACRL, National Conference, 1999, "Apply by Jan. 8 for info literacy program," 831; "Call for participation," insert (no. 1), 247; "Call for participation deadline nears," 379; "Detroit: a desktop travelogue for the 9th National Conference" \& photo., 669-71; "Detroit: expect a lot: it's more than just the Motor City" \& photos., 23-26; "Detroit libraries: check them out!" \& photo., 848-51; "Librarian \& faculty/administrator teams needed for ACRL 1999," 245, "November 1 deaclline for ACRL poster sessions," 655; "Oct. 15 deadline for ACRL scholarships," 566; "Offers 50 scholarship: to its National Conference," 485; photo., 146; "Presenters sought," 75; "Presenters sought for ACRL's 9th National Conference," 5; "Register by Jan. 18 and save money!," 829; "Register early and save!," 750; "Seeks proposals for poster sessions," 566; Tiger Stadium photo., 2

ACRL, "New titles from ACRL in 1998," 864

ACRL official documents, "Guidelines for distance learning library services," approved 1998, 689-94

ACRL, "Order Annual Conference audiocassettes, 574

ACRL: partners in higher education ( "Are you qualified to serve on the accreditation team?" Nelson, 269-72, comment, 436; "NASULGC's 110th annual meeting examines library concerns," 100-101, 113; "Provosts, libraries, and electronic information: reports from AAIJE and CNI," Jenkins, 420-22)

ACRL, President, "Candidates announced," 486-87; "Meet the candidates," 883; "Message" \& por., 854-55

ACRL, "Programs at the 1998 ALA annual conference," 440-41

ACRL, RBMS, Katharine Kyes and Daniel J. Leals American Book Prices Current Exhibition Catalogue Awards, 1998, 279-80; 1999,589

ACRL, "Register for leadership institute," 153

ACRL, "Resolution honoring Joseph A. Boissé on hiss retirement," 586

ACRL, "Resources, roles, and active learning covered in three new ACRL pulslications" \& photo., 407

ACRL, "Restructuring academic libraries available" \& pholo., 247

ACRL, "Revising the bylaws," 109

ACRL staff, "Meet the ACRL staff" \& ports, 875-77

ACRL, Standards \& Accreditation Com., "Outcomes assessment task force recommendations and resolution," 583; "Are you qualified to serve on the accreditation team? Survey results of six accrediting agencies," 26972, comment, 436
ACRL, STS, Eunice Rockwell Oberly Award, 1999, 589

ACRL, "The time to lead: ACRL seeks nominees for office," $284-85$

ACRL, "Topper leaves ACRL," 407

ACRL, ULS, "News from the University Libraries Section," 572-73

ACRL university library statistics, 1996-97 \& photo. LihraryResearch Center, 752

ACRL, "Values for the electronic information age," 853-77

ACIRL, Vice-President, "Message" \& port, 856-57

ACRL, WESS, Martinus Nijhoff International West European Specialist Study Grant, 1998, 280; 1999, 589

ACRL, "The year in review," $860-68$

"ACRL award winners, 1998," 862

"ACRL awards for 1999: honoring accomplishments and supporting professional development, "Briody, 589

"ACRL bylaws: a proposed revision," $108-13$

"ACRL candidates for 1999," 844-17

"ACRL chapter conferences 1998-1999," 654

"ACRL colleagues 1998," 657, 872

"ACRL developing National Information Literacy Institute," 6,8

"ACRI. discussion groups," 881

"ACRL endorses SPARC program," 565

"ACRL explores values in Washington, D.C.: highlights of ACRL programs at the ALA Annual Conference," Part 1 \& photos., 569-75; Part 2 \& photos., 676-81, 685

"ACRL honors the 1998 award winners: recognizing professional contributions and scholarly research," Briody, $274-80$

"ACRL journals," 863

"ACKL launches new data collection effort," 567

"ACRL memlxership statistics," 855

"ACRL Midwinter meetings in Philadelphia: a tentative schedule, "879-84

"ACIR offers 50 scholarships to its National Conference," 485

"ACRL offers practical leadership institute," 7

"ACRL 1998 president's l'rogram videos availalsle," 83031

"ACRL preconferences in D.C.: learn more about advocacy, instruction, or special collections," 193-95

"ACRL progranss and meetings," [AC1]-AC16

"ACRL publishes promotion and tenure book" \& photo., 75

"ACRL publishes three new books" \& photos., 752

"ACRL repon on academic librarians' scholarship avail able, 336

"ACRL section renamed Distance Learning Section," 48586

"ACRL seeks proposals for poster sessions, ${ }^{n} 566$

"ACRL slogan contest ended," 487

"AClRL Statistics Committee seeks data, 150

"ACRL wants you! Here's your chance to volunteer," 695 . 701

"ACRL's legislative agenda," 258

"ACRL's mission," 853

ARL, "ACRL endorses SPARC program," 565, clarification, 247; "George Washington University joins ARL," 830; "Texan Digital Library Alliance formed," 5-6; "Texas Tech joins ARL, ${ }^{n} 73$

"ASERL stats available," 485

"At the crossroads of information and culture: the 64th IFLA Conference" \& photo, Rader, 686-87

Atkinson (Hugh C.) Memorial Award, 1998, 274, 276; 1999, 589

"Ausburg College opens new library and technology center" \& photo., 333

Austin, Philip E., photo., 295

Autry Mus. of Western Heritage, "Rodeo Parade: in the Montana-Wyoming Dude Ranch Country" poster, (cover, no. 7)

"The Avalon Project" \& logo., rev. of, 118

"Award nominations," ACRL, 280 
Awards, 274-80 (11), 460, 584-85 (2), 589 (15), 753, 862

"The axe for the frozen sea - t the value of reading for academic librarians," Branch, 16, 35, comment, 153

Baker, Angee, appt., 202-10

Baker \& Taylor, Academic or Research Librarian of the Year Award, 1998, 275; 1999, 589; "Academic or Research Librarian of the Year Award resolution," 584

Baldwin, James, porn., 486

Bancroft, Janet, "No food, no drinks" \& posters, 330, 335

Banks, Patrick, "Cajun/Zydeco Music and Dance Exhibit" poster, (cover, no. 9)

Barnes and Noble, "Shop for out-of-print books on the Web," 832

Barry, Jeff, news note, 618

Beall, Jeffrey, "Guaranteed hits: how to make your library's Web site stand out in Web search engines," 160-62

Benson, James, appt., 716

"The Benton Foundation," rev. of, 371-72

Berteaux, Susan S., "Introducing database advisor: a new service that will make your research easier" \& photos., 409-12

Biggs, Bonnie, news note, 716; "The Tribal Library Project: interns, American Indians, and library services: a look at the challenges, ${ }^{n} 259-62$

"Biographical Dictionary" \& logo, rev. of, 452

"Biography" \& logo, rev. of, 452-53

Blackman, Betty, "Focus on the invited papers program: exciting programs to attend at National Conference" \& photos., 597-600

Blackwell, Nan, photo., 278

Blair, May, news note, 296

Bloom, Stephen, appt. \& port., 124

Bodi, Sonia, appt., 896

Boissé, Joseph A., "Resolution honoring Joseph A. Boissé on his retirement, ${ }^{n} 586$

I3ookplates, 334 (2)

"l3ookplates wanted," GERL nows, 150

Boyarski, Jennie S., retired, 44

Bozeman, Pat, photo., 574

Bradley, Doreen R., "HealthWeb: an Internet collaboration" \& photos., 338-40

Bradley, Lynn E., "Washington hotline," 30, 115, 366, 449, $524-25,607,707,786,886$

Branch, Katherine, "'The axe for the frozen sea ...': the value of reading for academic librarians, ${ }^{2} 16,35$, comment, 153

Breivik, Patricia, photo., 575

Brewer, Edward V., "Rodeo Parade: in the Montana-Wyoming Dude Ranch Country" poster, (cover, no, 7)

Briody, Jack, "ACRL awards for 1999: honoring accomplishments and supporting professional development," 589; "ACRL honors the 1998 award winners: recognizing professional contributions and scholarly research, ${ }^{\text {" } 274-80 ; ~ p o r t . ~} 875$

Brown, William E., Jr., photo., 586; "Rare book librarians prepare for the 19th century," 570-71; "Reclaiming theEverglades" \& photo., 895

Brown-Syed, Christopher, news note, 296

Brunvand, Amy, "Know thyself: a librarian uses the library," 80-81, 84

Buckley, Francis J., Jr., appt. \& port., 41-42

"Build your leadership skills," ACRL, 75

Bullington, Jeffrey S., "Tips for new librarians: what to know in the first year of a tenure-track position," 8588

Bunge, Charles, news note, 41

Burkhardt, Joanna M., "Do's and don'ts for moving a small academic library: fourteen helpful tips" \& photos., 499 503; photo., 500

Butcher, Karyle, appt., 798

Byrd, Theresa S, appt., 618
"Cafe in Ekstrom Library Lobby," U. of Louisville, photo, 5

Cain, Mark, "Only change is constant: three librarians consider what their jobs will be like in five years" \& port. $602-3^{\prime \prime}$

"Cajun/Zydeco Music and Dance Exhibit" poster, Banks, (cover, no.9)

"California community colleges create purchasing consortium, ${ }^{* 749-50}$

CSU, Fresno, Arne Nixon Center for the Study of Children's Literature, 3; "No food, no drinks" \& posters, 330, 335

"CSU Northridge breaks ground" \& photo., 753; "More libraries choose Endeavor," 753

CSU, San Marcos, "The Tribal Library Project: interns, American Indians, and library services: a look at the challenges," 250-62

"CSU, San Marcos offers interactive exhibit," 149

"Call for contributions," Mc/ournal: the journal of academic media librariansh ip, 74

"Call for participation," ACRL, National Conference, 1999, inser (no. 1), 247

"Call for participation deadline nears," ACRL, 379

"Call for 'The way I see it' essays," CERL news, 495

Camphell, Stan, "A diminished thing: what are we losing by favoring electronic access?, 263-64

"Candiclates for ALA President announced," 73-74

Cardman, Elizabeth R., "New in the ALA Archives" \& photo., 751

Carle, Daria O., photo., 9

Carpenter, Kathryn H., appt. \& port., 896

Caruso, Frank, photo., 832

Casalini, Mario, "Memorial resolution," 582

Case, Mary, "Academic community sets agenda to reclaim scholarly publishing, 655

Casey, Carol, "Web rings: an alternative to search engines," $761-63$

"CDC World Wide Weh site review" \& logo, rev. of, 37273

Cech, Tom, photo., 9

"Celebrate National Library Week" poster, 151

"Celebrate the freedom to read!," 486

"Center for responsive politics" \& logo, rev. of, 709-10

"Ceremony commemorating the 25th Anniversary" \& photo., U.S. Naval Academy, 830

"The challenge to change: creating cliversity in libraries" \& photos, Goldberg, 840-42

Chang, Ching, "East Asian studies: sites to help meet the growing demand for information" \& logos, 514-520, correction, 606

Chao, Sheau-yueh J., "East Asian studies: sites to help meet the growing demand for information" \& logos, 514-520, correction, 606

"Chapter conferences 1998-1999," ACRL, 654

"Chapter relations task force report," ACRL, 585

"The Chemical Scorecard," rev. of, 789

Chiang, Belinda, "East Asian studies: sites to help meet the growing demand for information" \& logos, 514520 , correction, 606

Choice, "Oct. 16 deadline for contest to name Choice Web service," 566-67

Chressanthis, June, "Investments and personal finance: these sites can help you make informed decisions" \& logos, 90-94

Christic, Manson \& Woods, Inc., Rare Books and Manuscripts Librarianship Award, 1999, 589

Chumakov, Boris, retired, 719

Cichon, Joan, photo., 277

Clack, Mary Beth, “The President's program: O'Donnell and Wheatley-dynamic speakers you shouldn't miss," 838

Clarification, 247

Clark, Kathleen A., "Cruising for travel information: visit these sites when you plan your next vacation" \& logos, 427-31 
Clark, Susan E., revs. ("Biographical Dictionary" \& logo, 452; "Biography" \& logo, 452-53)

Clemens, Samuel, port., 486

CLIP notes, ACRL, $\# 26,75$

CNI, "Provosts, libraries, and electronic information: reports from AAHE and CNI," 420-22

Cochran, Richard M., appt. \& port., 538-39

Coker, Aurelia, photo., 278

"Collectiondevelopment.com: using Amazon.com and other online bookstores for collection development" \& photo., Fusich, 659-61

Coll. of Wm. \& Mary, photo. 832

CERL news, "Bookplates wanted," 150; "Call for "The way I see it' essays," 495; "Feature your collection," 895; "Feature your collection on the cover," 147; Hotlinks to 'Internet Resources', "167, 344; " Internet resources"

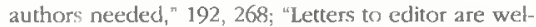
come," 152; "Statement of ownership and management," 767; "Submission guidelines," 29

CGRL news nel, "Hotlinks to "Internet resources'," 344

"College library management video available from ACRL," 246-47

Collins, John W., III, "A value that bonds: the Jibrary as a uniquely democratic institution," 355-56

Colo. State U., Fort Collins, "Don't lead a road warrior existence: what Access Services can do to survive, ${ }^{n}$ $784-85$

"The Colorado union catalog project: expandling the OhioLINK and ORBIS concepts," Dedrick, 754-56

"Colorado's catalog on the Web" \& logo, U. of Colo., 149

Colvin, Elese, retired, 210; retired \& port., 620

ClC, "Healthweb: an Internet collaboration" \& photos., $338-40$

Community College Learning Resources Achievement Awards, 1998, 277

Community College Learning Resources/Library Achievement Award, 1998, 585; 1999, 589

"Compilation of core information literacy competency/ outcomes for undergraduates," Lindauer, 350

Conference circuit ("ACRL at the Midwinter Meeting," 174 81, 207; "ACRL explores values in Washington, D.C." \& photos., 569-75; "ACRL Midwinter meetings in Philadelphia," 879-84; "At the crossroads of information and culture" \& photo., 686-87; "The challenge to change" \& photos., 840-42; "Crimea '98" \& photo., 596, 603; "Detroit: expect a lot" \& photos., 23-26; "Detroit libraries" \& photo., 848-51; "The eighth offcampus library services conference," 418,431 ; "Focus on the invited papers program" \& photos., 597-600; "From black-and-white TV to rich interactive learning environments," 683-85; "Information literacy," 17172; "Information provision, ${ }^{\circ}$ 604-6; "Institute for Information Literacy Immersion '99," 782-83; "Integrating information literacy into the curriculum, ${ }^{n} 347,352$ "The International BOBCATSSS Symposium, ${ }^{n} 273,285$; "Internet Librarian '97," 183-84; "Living the future II," 494-95; "New learning environments," 509-10; "Performance measurement in libraries and information services," 250-51; "Technology exhibits at ALA" \& photos., 577-80)

CQ, Marta Lange/CQ Award, 1998, 279; 1999, 589

"Consortium to build information hub for southeast Michigan, ${ }^{\prime} 749$

Constancy and change in the worklife of research university librarians \& photo., Watson-Boone, 752

Constantinou, Constantia, rev. ("Ethics Updates"), 789-90

Copeland, Jud, appt. \& port., 124

"Cornell establishes digital institute," 8-10

Corrections, 247, 373, 540, 606, 851

"Creating the developmental teaching portfolio: a great tool for self-assessment" \& illus., Lally, 776-78

"Creation of a Web list for clinical disciplines: a step-bystep account of the 'Webliography' process" \& photo., Mathias, $768-70$
Creech, John, rev, ("Volcano World"), 528-29

"Crimea '98: libraries and associations in the transient world" \& photo., Pourciau, 596, 603

Criteria for Promotion and Tenure in Academic Libraries (CLIP note \#26) published, ACRL, 75

Cron, Sarah Mont, appt., 716

Croneberger, Robert B., deceased, 462

"Crossroads of a profession: reflections of a yearlong discussion about electronic information," Hisle, $504-5$

"Cruising for travel information: visit these sites when you plan your next vacation" \& logos, Clark, 427-31

Cullars, John, photo., 678

"A cultural awakening: the Harlem Renaissance revisited" \& photo., Nelson, 656

Curley, Arthur, deceased \& port., 381

Curtis, Robert, news note, 459

Curzon, Susan, photo., 753

\section{D}

da Conturbia, Sandra, "Government information: a guide to governments here and abroad" \& logos, 764-67

da Cunha, Murilo B., appt., 896

Damico, James A., retired \& port., 719

Daniel, Eileen, retired, 719

Dartmouth Coll., "Keeping current, keeping sane! A Web tutorial for coping with information overload" \& photo., $248-49$

"Date set for 'Learning to Teach' preconference," ACRL, IS, 75

Davis, Darlena, port., 875

Davis, James, retired $\&$ port., 126

Davis, Mary Ellen K., "In the News, ${ }^{4} 4,72,148,240,332$, $404,484,564,652,748,828$; "News from the field," 5$10,73-75,149-51,241-47,333-36,405-7,485-88$, 565-67, 653-56, 749-53, 829-32; photo., 574; port., 875

Deaths, 44, 126, 211, 299, 381, 462, 541, 621, 801, 898

"Dedicated UC-Santa Cruz librarians continue to give," 831

Dedrick, Anthony J., "The Colorado union catalog project: expanding the Ohio-LINK and ORBIS concepts," 754 56; "Libraries participating in Prospector's initial phase," 755

"Defending the freedom to read: a reflection of personal values and censorship," Maloy, 169-70

"Define ACRL contest deadline near, ${ }^{n} 75$

Dempsey, Paul R., correction, 540

Dempsey, Paula R., correction, 540

DePellegrin, Tracey, "Technology exhibits at ALA: a look at what's new" \& photos., $577-80$

Derwent Information (London), "... and the Thomson Science and Technology Group ${ }^{\circ} 750$

"Detroit: a desktop travelogue for the 9th National Conference" \& photo., Kane, 669-71

"Detroit: expect a lot: it's more than just the Motor City" \& photos., Kane, 23-26

Detroit Area Library Network (DALNET), "Consortium to build information hub for southeast Michigan," 749

"Detroit libraries: check them out!" \& photo, Kane, 84851

Didier, Elaine K., appt. \& port., 124; photo., 575

Diehl, Alice, retired, 44

"Digital copyright legislation pending: an open letter to the library community, "76

"A climinished thing: what are we losing by favoring electronic access?" Campbell, 263-64

"Directory of ACRL accreditation advisors," 242-43

"Distance education: delivering instruction in cyberspace" \& logos, Lorenzen, 342-45

"DLS/IS seeks poster sessions/presentations for 1999 program," 65455

Distinguished Education and Behavioral Sciences Librarian Award, $1998,277-78 ; 1999,589$

Dittemore, Margaret, news note, 209 
Doctoral Dissertation Fellowship, 1998, 460; 1999,589

Dollerschell, Allen L., retired, 126

"Don't lead a road warrior existence: what Access Services can do to survive," Farmer, 784-85

"Don't miss Dec. 1 award deadline," ACRL, 753

Dopp, Bonnie Jo, news note, 459

"Do's and don'ts for moving a small academic library: fourteenhelpful tips" \& photos., Burkhardt, 499-503

Douglas, Aaron, Fisk University murals, (cover, no. 2)

"Douglass: archives of American public address," rev. of, $117-18$

Dowler, Lawrence, retired \& port., 380

"Draft of ALA Intellectual Freedom statement on Web," ALA, 246

Drake, Miriam, news note, 798

Drew, Wilfred, rev. ("Tobacco Control Archives" \& logo), 529

Drick, Beverty, photo., 277

Drobnicki, John A., rev. ("The Felix Posen bibliographic project on antisemitism" \& logo), 891

Dudley (Miriam) Instruction Librarian Award, 1998, 27879; 1999, 589

Dumouchel, Bernard, appt., 619

\section{E}

"East Asian studies: sites to help meet the growing demand for informarion" \& logos, Chang, 514-20, correction, 606

Eaton, Nancy, photo., 840

Eberhart, George M., "New publications," 36-37, 119-20 (\& photo.), 203-4 ( photo.), 291-92 (\& photo), 37475 \& photo., 454-55 (\& photo.), 530-33, 613-14 (\& photo.), 711-13 (\& photo.), 792-94 (\& photos.), 892

EBSCO, Community College Learning Resources Achievement Awards, 1998, 277; Community College Learning Resources/Library Achievement Award, 1998, 585; Community College Learning Resources/Library Achievement Awards, 1999, 589

EBSCO, "Indiana selects ElBSCO to offer access to virtual library" 246

"EBSCO and Springer Verlag partner to provide journals online," $653-54$

EDUCAUSE, "Hawkins selected to lead EDUCAUSE," 4067

Edwards, Doralyn H., rev. ("Center for responsive politics" \& logo), 709-10

"The eighth off-campus library services conference: a look at one of the major growth areas in academic libraries," LaGuardia, 418, 431

Fland, Tom, photo., 749

Elbert, Arthur, photo. 753

Elkins, Kimball C., deceased, 299

Elkordy, Angela, rev. ("Infoplease.com"), 790

Ellis, Marie C., retired, 380

Emmons, Mark, revs. ("Erhnologue" \& logo, 890-91; "Jon's Homeschool Resource Page" \& logo," 611)

Endeavor Information Systems, "Library of Congress selects Endeavor for ILS," 488; "More libraries choose Endeavor," 753

English, Ray, "Financial report" \& port., 870-74; photo., 584,869

"Enter the 'Define ACRL' contest," ACRL, 10

"Environmental engineering: protecting health and nature" \& logos, Jordan, 834-37, 842

Erickson, AnnaMarie, news note, 296

Errata, 247, 373, 540, 606, 851

Estabrook, Leigh, photo., 598

"Estacado Library Information Network formed," 405

"Ethics Updates," rev. of 789-90

"Ethnologue: languages of the world" \& logo, rev. of, $890-91$

Eunice Rockwell Oberly Award, 1999, 589

"Europeans join efforts to expand competition in journal publishing," 829-30

Everglades collection, U. of Miami, photo., 826

\section{F}

Fagerheim, Britt, revs. ("The Avalon Project" \& logo, 118; "The Benton Foundation," 371-72)

Fägerstrom, David, ploto., 9

"Faith in librarians restored by Branch's praise of reading," Tudiver, letter to the ed, 153

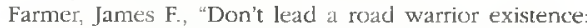
what Access Services can do to survive," 784-85

Fatzer, Jill B., "NASULGC's 110th annual meeting examines library concerns: copyright, scholarly publishing, and technology discussed," 100-101, 113; photos., 584 869; "Plans for ACRL" \& port, 103-5

"Feature your collection," CERL neus, 895

"Feature your collection on the cover," CERL news, 147

"Feature your library in CERI news," 884

"The Felix Posen bibliographic project on antisemitism" \& $\operatorname{logo}$, rev of 891

Ferguson, Chris, news note, 41

Field, Judith J., SLA president, "Digital copyright legislattion pending: an open letter to the library community, 76

Fisk University murals, Douglas, (cover, no. 2)

Flaxbart, David, news note, 798

Focus on collections ("Reclaiming the Everglades" \& photo.: Brown, 895)

Focus on libraries ("Renovating for technology" \& photo.: Nutty, 414-16)

"Focus on the invited papers program: exciting programs to attend at National Conference" $\&$ photos., Blackman, $597-600$

Forbes, Loren, retired, 380

Ford, Barbara J, ALA president, "Digital copyright legislation pending: an open letter to the library community," 76; "Go glohal! Ten ways to play your role on the world state" \& poster, 78-79

Ford, Sylverna, photo., 749

Fortson, Judith, retired, 801

"Foundation Center," rev. of, 371

Fradkin, Bernard, "Fradkin and Oakton Community College receive Community College awards" \& port., 277; photos., 584, 869; "Receives EBSCO award," 585

Frazer, Stuart, news note, 618

"From audiovisual to media resources," Provine, 358

"From black-and-white TV to rich interactive learning environments: the 14th Annual Conference on Distance Teaching and Learning," Hinchliffe, 683-85

Fusich, Monica, "Collectiondevelopment.com: using Amazon.com and other online bookstores for collection development" \& photo., 659-61

G

Gale Group, "Thomson mergers form Gale Group," 750

Gale Research, "Thomson mergers form Gale Group," 750 Galloway, Margaret, retired, 210

Garcia, Susan A. Vega, rev. ("Institute for Puerto Rican Policy's IPRNet" \& Iogo), 453

Garrett, Jeffrey, "Receives the Martinus Nijhoff West European Study Grant," 280

Gasaway, Laura N. "Lolly", "Wins Marta Lange/CQ Award" \& port., 279

Gass, William H., port., 569

"Gateways to social work/welfare on the net: practice wisdom to go" \& logos, Summers, 163-67

Genung, Marie, deceased, 299

Geo. Wash. U., "Pennsylvania Avenue from U.S. Treasury, Washington, D.C." (cover, no. 5): "Renovating for technology: partnerships produce quick results: how a little team work went a long way" \& photo., 414-16

"George Washington University joins ARL," 830

Getty Information Institute, "UCLA and Getty offer summer institute," 832

Getz, Malcolm, photo., 598

Giglio, Francis S., letter to the ed., 436 
Giuse Nunzia B appt, 896-97

Glazer, Fred, deceased, 211

"Global reach to Northern Ireland libraries," McPhail, 244

"Go global! Ten ways to play your role on the world

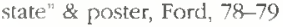

Godfrey, Arthur, photo., 295

Godow, Michael, "Members assess ACRL prior to the new millennium: results of the 1997 member survey, "44246; port, 876

Goldberg, Martin, "The challenge to change: creating diversity in libraries" \& photos., $840-42$

Gomez, Martin, "Meet the candidates for ALA president: cast your vote in the election this spring" \& port. $186-89,195$

Gordon, William R., "Appointed ALA executive" 5

"Government information: a call to action," Gray, 255

"Government information: a guide to governments here and abroad" \& logos, da Conturbia, 764-67

Graf, Francine, port., 875

Graham, Peter S., appt. \& port., 539

"Grants and acquisitions," Young, 38-39, 121-22, 206-7, $294-95,376-77,456-57,535-36,616-17,714-15,795-$ 96, 894

Grants (by grantee): Angelo State U., 714; Atlanta Hist Ctr., 616; Bethune-Cookman Coll., 294; CSU, Fresno, 38. 535; Campbell U., 714; CUNY, 616, 715; Dillard U. 294; Earlham Coll., 457; Franklin Coll., 457; Frick Art Ref. Lib., 376; Friends of Libraries USA, 294; Furman U., 795; Hampton (Va.) U., 294; Harvard U., 535 Hillscale Coll., 714 Huntington Coll., 457; Ind. Insti tute of Tech., 457; Ind U., Bloomington, 294; Jarvis Christian Coll., 294; Johns Hopkins U., 376; Johnson \& Wales U., 206; LeMoyne-Owen Coll., 294; Libraries for the Future, 294; Naval Observatory Lil). 456; Navy Dept. Lib, 456; New School for Social Research, 39 Oakland City U., 457; Portand State U., 456, 535; Rider U., 206; Rose-Hulman Institute of Tech, 457; Rust Coll. 294; St. Joseph's Coll., 457; St. Mary's Coll, 457; Saint Mary-of-the-Woods Coll, 457; Smith Coll., 121, 535 SOLINET, 39, 121; So. Ill. U., Carbondale, 38; So. Methodist U. 795; So. U. 535; Southwest Mo. State U., 456, 535; Spelman Coll., 294; State Historical Soc of Wis., 38; SUNY, Buffalo, 795-96; Syracuse U., 376; Tri-State U., 457; Tufts U., 294; Tuskegee (Ala.) U. 294; U. of Evansville, 457; U. of Ga., 456; U. of Iowa 714, 795: U. of Md., College Park, 121; U. of Mich., 38-39; U. of Minn., 38; U. of N.D., 206; U. of Ore. 616; U. of Penn., 456; U. of Pittshurgh, 616, 894; U. of Rochester, 795; U. of S.C., 294; U. of S. Fla, 121, 894 U. of Tenn., 714; U of Calif. (Berkeley, 616; Irvine, 894 LA, 206, 456, 714; Santa Cruz, 121, 714, 795); U. of Ill., U-C, 38; UNC, $\mathrm{CH}_{3} 376,616-17,714$; Va. Union U., 294: Wabash Coll, 457; Wake Forest U., 714; Warren Wilson Coll., 535-36; Wash. U., 376; Wilberforce (Obio) U., 294; Wi]ey Coll., 294; Wofford Coll. 795; Xavier U. of La., 294 Yale U., 715

Grants (by grantor): Ahmanson F, 206, 456; Alden (George L.) Trust, 206; Amer. Film Institute Natl. Ctr. for Film \& Video Preservation, 294; Amer. Institute of Physics, 894; Ameritech, 714; Andersen (Elmer L. \& Eleanor J.) F., 206; Angle, A. Bayard, 121, 894; Asheim, Lester E. 376; Baker F., 206; Basin Electric lower Cooperative, 206: Berger Family Technology Transfer Endowment, 294; Bremer (Otto) F., 206; Buhl F., 616; Coleman, Ruth, 121; Cutlip, Scott M., 38; Dakota Gasification Co., 206; Delmas (Gladys Krieble) F., 39, 376; Dept of Defense, 456; Gregg (John Rohert) Fund, 206; Harte, Edward H. \& Houston H., 714; Ill. Board of Higher Educ, 38; Infotrieve, 714; IMIS, 894; Intel Corp., 61617; Japan F., 795; Kellogg (W. K.) F., 38; Kingfisher Flat F., 714; Lee, Jerry, 121; LC, 714; LSTA, 456, 535; Lilly Endowment, 294 (12) 457 (12); Loker, Katherine B., 535; Long (J. M.) F., 121; Louisiana Board of Regents, 535; Lynch, Thomas Jack, 714; Mellon (Andrew
W.) F, 294, 376, 715, 705 (2); Messinger, Martin E 795: NEH, 38-39, 39, 121, 456, 714; NHPRC, 456 (2) 535, 616; NSF, 795-96; Nissho Iwai Amer. Corp., 616; Nixon, Arne, 38; Pew, Rob, 535-36; Plummer, Helen Ingram, 376; Reed F., 715; Rockwell Internatl., 795; Salloch, William, 535; Silberstein, Stephen M., 616; Simmons, Ruth, 121; Tarkanian, Jerry \& Lois, 535; Thaw (Eugene V. \& Clare E.) Charitable Trust, 376; Time Warner Trust, 894; U.S. Dept. of Commerce, 38; U.S Natl. Telecommunications \& Info Admin., 616; U.S Dept. of Commerce, 121; USDE, 38; U.S. West F., 206

Vilournum F., 294; Von Rosentiel, Werner, 121

Gray, Carolyn M. "Government information: a call to action," 255

Greenman, Barb, photo., 9

"Ground broken for Penn State Harrisburg library" \& photo., 488

"Guaranteed hits: how to make your library's Web site stand out in Web search engines," Beall, 160-62

"Guidelines for distance learning library services," ACRL, approved 1998, 689-94

"Guidelines for media resources in academic libraries: a draft," ACRL, 357-65

\section{H}

Hahn, Karla L., rev. ("Agricola" \& Iogo), 710

Hamaker, Charles $A$. "Kleiner and Hamaker receive $K$. G SaurAward," 276; news note, 41

Hamann, Edmund G. (Ted), retired \& port, 620

Hamburger, Susan, "The challenge to change: creating diversity in libraries" \& photos., 840-42

Hamilton, William, "The manner in which the American Colonies Declared Themselves Independant of the King of England . . . July 4, 1776," (cover, no. 6)

Hanawalt, Victoria, news note, 716

Hardesty, Larry, photo, 586; "Plans for ACRL, "105-7 (port 103); port., 437

Harris, Sarneisa, photo., 278

Harter, Stephen $P_{\text {. }}$, news note, 378

Hartman, Cathy Nelson, news note, 618

Harvard U., Kaladlit Okalluktualliait: woodcut illus. (cover, no. 3)

Hawkins, Brian L., "Selected to lead EDUCAUSE," 406-7

Hay, Fred I., news note, 209

Hazen, Dan C. "Making collections work: remote access and browsing, "97-99, 113

"Healthfinder" \& logo, rev of, 528

"HealthWel: an Internet collaboration" \& photos, Bradley, $338-40$

Hedherg, Jane, "Preservation news," 32, 116 (correction, $373), 199,286,368,373,450,527,609,708,788,888$

Helbig, Jack, port., 876

"Help for nonprofits," 206

Herman, Elizabeth (Betty), retired, 801

Herman-Morgan, Dehorah, news note, 459

Hightower, Christy, "Introducing database advisor: a new service that will make your research easier" \& photos., 409-12

Hinchliffe, Lisa Janicke, "From black-and-white TV to rich interactive learning environments: the 14th Annual Conference on Distance Teaching and Leaming," 683-85

Hirshon, Arnold, "Named winner of Atkinson Award" \& port., 274, 276

Hisle, W. Lee, "Crossroads of a profession: reflections of a yearlong discussion about electronic information, ${ }^{12} 504$ 5; "Message from the president" \& port., 854-55; pho tos. $562,584,586,869$

Historical Soc of Penn., The woodlands in winter (water color) (cover, no. 11)

Hoffman, Elaine, rev. ("CDC World Wide Web site review" \& logo), 372-71

Holmes, Barbara, "Minority student success: librarians as partners, " 496-98

Hood, Joan M., retired \& port, 620-21 
Hoover, Richard, deceased, 898

Horne, Doug, rev. ("NARA Archival information locator (NAIL)"), 202

"Hotlinks to 'Internet Resources"," CERL news, 167, 344 "How successfully do users search the Web? One realtime site allows you to "spy' on searchers," Nims, 155 58

Huchner, Joseph, retired \& port., 211

Hugh C. Atkinson Memorial Award, 1998, 274, 276; 1999, 589

Hunt, Judith, photo., 597

Hupp, Stephen L., rev. ("Policy.com" \& logo), 612

Hyman, Ferne, photo., 146

I

"If you're considering a tribal library internship," 261

"Imagining the Learning Library' tape available," ACRL. 150

"In the News," Davis, 4, 72, 148, 240, 332, 404, 484, 564, $652,748,828$

"Indiana selects EBSCO to offer access to virtual library," 246

"Indiana University named to run Internet2 network," 566 "Infoplease.com," rev. of, 790

IAC, "Thomson mergers form Gale Group," 750

"Information literacy: best practices and models," Wilson 351-52

"Information literacy: the professional issue: subjects addressed at the Third National Australian Conference," Rader, 171-72

"The Information Literacy IQ (Institutional Quotient) Test," Oberman, 348-49

"Information provision: an international seminar on politics and strategy," Wilson, $604-6$

Initialives, "New Web journal seeks submissions," 334

Innovation in Instruction Award, 1908, 278; 1909,589

"The Institute for Information Literacy: formal training is a critical need," Oberman, 703-5

"Institute for Information Literacy Immersion '99: an invitation to apply," ACRL, 782-83

"Institute for Puerto Rican Policy's IPRNet" \& logo, rev of, 453

ISI, " $\ldots$ and the Thomson Science and Technology Group," 750

ISI, Doctoral Dissertation Fellowship, 1998, 460; 1999 589; Samuel Lazerow Fellowship, 1998, 276-77; 1999 589

Instruction Publication of the Year Award, 1999, 589

"IS Think Tank III participants sought," ACRL, 750-52

"Integrating information literacy into the curriculum: how is your library measuring up?," Oberman, 347, 352

"The International BOBCATSSS Symposium: shaping the knowledge society," Pourciau, 273, 285

Internet, "Shop for out-of-print books on the Web," 832

"Internet Librarian '97: the latest developments," Lederer, $183-84$

Internet resources ("Cruising for travel information" \& logos, 427-31; "Distance education" \& logos, 342-45. "East Asian studies" \& logos, 514-20, correction, 606; "El Niño" \& logos, 663-67; "Environmental engineering" \& logos, 834-37, 842; "Gateways to social work/ welfare on the net" \& $\operatorname{logos}, 163-67 ;$ "Government information" \& logos, 764-67; "Investments and personal finance" \& logos, 90 94; "Locating public domain images" \& logos, 11-13; "Nutrition and vegetarianism" \& logos, 265-68; "A world in motion" \& logos 591-94)

Internet resources, "Hotlinks to "Internet Resources," CERL news, 167

"Internet resources" authors needed," CERL news, 192; CERL news, 268

"Internet reviews," Amato, 34-35, 117-18, 201-2, 288-89 $371-73,452-53,528-29,611-12,709-10,789-90,890-91$

Internet2, "Indiana University named to run Internet2 nerwork," 566
"Introducing database advisor: a new service that will make your research easier" \& photos., Hightower, 409-12

"Investments and personal finance: these sites can help you make informed decisions" \& logos, Lewis, 90-94 Irwin, Marie, news note, 618

Isenstein, Ellen, appt. \& port., 124-25

Jackson, David, deceased, 801

Jenkins, Althea $H_{\text {. " }}$ Letter from the executive director" \& port., 858-59; "Members assess ACRL prior to the new millennium: results of the 1997 member survey, "44246; photos., 584, 586, 869; port., 876; "Provosts, libraries, and electronic information: reports from $\mathrm{AAHE}$ and CNI," 420-22

Jennings, Tom, retired, 621

Jewish Theological Seminary, Leab Award, 279-80

Johns, Francis A., deceased, 898

"Johns I Iopkins University establishes Digital Knowledge Center, 246

Johnston, Wanda, Library and learning resource programs: evaluation and self-siludy \& photo., 752

"Join the leadership discussion," ACRL, 880

Jones, Maryhelen, appt. \& port, 897

Jones, Sarah I owlin, deceased, 126

Jones, Walter, "Kudos to Newman: librarians sbould publish," letter to the ed., 152

"Jon's Homeschool Resource Page" \& logo, rev. of, 611

Jordan, Kelly, "Environmental engineering: protecting health and nature" \& logos, 834-37, 842

Jordan, Robert L. "Jay", appt., 459

Josey, E. J., photo., 840

"JSTOR establishes joumal conversion faciliry at Princeton," 75

"JSTOR usage rises 363 percent and establishes a UK site, 334,336

Jubinski, Sarah B., retired, 719

"Justice information center" \& logo, rev. of, 709

K. G. Saur Award for Best College \& Research Libraries Article, 1998,$276 ; 1999,589$

Kaladlit Okalluktualliail, woodcut illus., (cover, no. 3)

Kane, William P., "Detroit: a desktop travelogue for the 9th National Conference" \& photo., 669-71; "Detroit: expect a lot: it's more than just the Motor City" \& photos., 23-26; "Detroit libraries: check them out!" \& photo. 848-51

Kapoun, Jim, "Teaching undergrads WEB evaluation: a guide for library instruction," 522-23

Kaser, James A., appt., 897

Kassanoff, Mady, photo., 9

Katharine Kyes and Danicl J. Leab American Book Prices Current Exhibition Catalogue Awards, 1998, 279-80; 1999,589

Keeley, I3arbara, photo., 277

“Keeping current, keeping sane! A Web tutorial for coping with information overtoad ${ }^{n}$ \& photo., Rinaldo, 24849

Kelly, Julia A., "HealthWeb: an Internet collaboration" \& photos., 338-40

Kennedy, David Johnson, The woodlands in winter (watercolor) (cover, no. 11)

Kettner, Dorothy Hagen, retired, 801

Kiewitt, Fva L., news note, 41: "Selected for EBSS Award" \& port., 277-78

King, Angus, photo., 8

"King's College Library wins award" \& photo., 150-51

Klassen, Robert L., retired, 719

Kleiner, Jane P., "Kleiner and Hamaker receive K. G. Saur Award" \& port, 276; news note, 41

Kniffel, Lconard, news note \& port., 459

Knight, Lorrie A., "Locating public clomain images: some sites to visit to enhance your Wels page" \& logos, 11-13

"Know thyself: a librarian uses the library," Brunvand, $80-81,84$ 
Kochan, Roman V., appt. \& port., 716-17

Kranich, Nancy, "Kranich, Schmidt to compete for ALA presidency, ${ }^{n} 830$

"Kranich, Schmidt to compete for ALA presidency," 830

"Kudos to Newman: librarians sbould publish," Jones, letter to the ed., 152

L

LaGuardia, Cheryl, "The eighth off-campus library services conference: a look at one of the major growth areas in academic libraries," 418, 431

Lákos, Amos, "Performance measurement in libraries and information services: a report from the second Northumbria International Conference," 250-51

Lally, Ann, "Creating the developmental teaching portfolio: a great tool for self-assessment ${ }^{n} \&$ illus., 776-78

Lambert, Jodie, photo., 508

Lange (Marta)/CQ Award, 1998, 279; 1999, 589

LaRosa, Julius, photo., 295

Lazerow (Samuel) Fellowship, 1998, 276-77; 1999, 589

Leab (Katharine Kyes and Daniel J.) American Book Prices Current Exhibition Catalogue Awards, 1998, 279-80; 1999, 589

Leadership and learning ("Leadership through the lens of leaming" \& port., 673-74; "The President's program," 838)

"Leadership through the lens of learning: a look at the role of the librarian for the new century" \& port., Sullivan, 673-74

"Learning to teach will be offered in D.C.," ACRL, 9

Lederer, Naomi, "Internet Librarian '97: the latest developments," 183-84

Lee, Minja, retired, 621

Lehman, Lois J., news note, 41

Lehmann, Stephen, photo., 678

Leonhardt, Thomas W., appt. \& port., 209

Lessin, Bart, photo, 146

Letters, 152-53, 436, 763

"Letters to editor are welcome, ${ }^{n}$ CERL Neus, 152

"Letters to the editor," 152-53

Leung, Shirley, appt. \& port., 539

Levinson, Harry, photo., 377

Lewis, Janice S., "Investments and personal finance: these sites can help you make informerl decisions" \& logos, $90-94$

$\mathrm{Li}, \mathrm{Xjaodong,} \mathrm{"Government} \mathrm{information:} \mathrm{a} \mathrm{guide} \mathrm{to} \mathrm{gov-}$ ernments here and abroad" \& logos, 764-67

"Librarian \& faculty/administrator teams needed for ACRL 1999," 245

"Libraries participating in Prospector's initial phase," Dedick, 755

Library and learning resource programs: evaluation and self-study \& photo., Johnston, 752

LC, "National Digital Library competition," 617

"LC awards preservation contract," 151

"The Library of Congress country studies" \& logo, rev. of, 117

"Library of Congress selects Endeavor for ILS," 488

"LC sponsors NSFs Digital Libraries Initiative-phase 2," 336

Library Research Center, ACRL university library statistics, 1996-97 \& photo., 752

Lichtenstein, Art, "Minority student success: librarians as partners," 496-98

"Life Magazine Home Page" \& logo, rev, of, 288

Lindauer, Bonnie Gratch, "Compilation of core information literacy competency/outcomes for undergraduates," 350 ; "Integrating information literacy into the curriculum: how is your library measuring up?" 347,352

"Living the Future II: organizational changes for success," Zambella, 494-95

"Living the Future II in Arizona," 74

"Locating public domain images: some sites to visit to enhance your Web page" \& logos, Knight, 11-13

Long, Laurel, "Miami Book Fair International" poster, 15th ed., (cover, no. 10)

Long, Sarah Ann, "Meet the candidates for ALA president: cast your vote in the election this spring" \& port, 186-89, 195
Lorenzen, Michael, "Distance education: delivering instruction in cylorspace" \& logos, 342-45

Los Alamos Natl. Lab, "Wins award," 151

Lovett, Robert W., deceased, 299

Lowe, William Clifford, deceased, 621

Lowry, Charles B., news note, 716

Luck, DeAnne, revs. ("The Chemical Scorecard," 789; "Uncle Sam," 34)

Lutzker, Marilyn, retired, 621

Lynch, Clifford, photo., 598

M

Ma, Wei, "QB online: how an old-fashioned question board went electronic" \& photos., 772-74

MacAdam, Barbara, photo., 575

McAdoo, Monty L., "The Mansfield protocol for laptop computer circulation: how a library can provide its own technical support" \& photo, 507-8, comment, 763

McCarthy, Connic Kearns, photo., 832

McCombs, Gillian, appt. \& port., 297

McCray, Alexa T., appt., 125

MacDougall, Hamiett, appt. \& port, 717

McFadden, Laurie L., letter to the ed., 763; "Making history live: how to get students interested in university archives" \&photos., 423-25

Mcjoumal: the journal of academic media librariansbip, "Call for contributions," 74

McKimmie, Tim, news note, 209

McMahon, Timothy E., rev. ("Monthly Catalog of United States Government Publications (MOCAT)" \& logo), 288-89

McManus, Mark G. R., "Neither Pandora nor Cassandra: library services and distance education in the next decade," 432-35

McPhail, Martha, "Global reach to Northern Ireland libraries," 244

McQuillan, David C., news note, 41

Madison, Olivia M. A., appt. \& port., 798

Maes, William, appt., 619

Mahar, Mary Helen, deceased, 381

"Making collections work: remote access and browsing," Hazen, 97-99, 113

"Making federal work-study work: four steps that one library uses to hire students" \& photos., Young, 49092, 525

"Making history live: how to get students interested in university archives" \& photos, McFadden, 423-25

Maloy, Frances J., "Defending the freedom to read: a reflection of personal values and censorship," 169-70

Maltese, Susan, photo., 277

"The manner in which the American Colonies Declared Themselves Independant of the King of England July 4, 1776," Hamilion, (cover, no. 6)

"The Mansfield protocol for laptop computer circulation: how a library can provide its own technical suppon" \& photo., McAdoo, 507-8, comment, 763

Mansfield U., "The Mansfield protocol for laptop computer circulation: how a library can provide its own technical support" \& photo., 507-8, comment, 763

Mariner, Vincent A., "El Niño: facts, figures, images, and predictions" \& logos, 663-67

"Marquette Univ, receives $\$ 10$ million gift for new library," $74-75$

Marta Lange/CQ Award, 1998, 279; 1999, 589

Martin, Mary, photo., 749

Martinus Nijhoff International West European Specialist Study Grant, 1998, 280

MIT, photo., 487

Mathias, Jody H., "Creation of a Web list for clinical disciplines: a step-by-step account of the 'Webliography' process" \& photo., 768-70

Matson, Susan A., news note, 538

Maxwell, John, deceased, 541

Mayzel, Judith, photo., 277 
Meadows, fudith A., AALL president, "I Digital copyright legislation pending: an open letter to the library community," 76

Meehan, Mary M., deceased, 299

"Meet the candidates for ALA president: cast your vote in the election this spring" \& ports., Gomez \& Long, $186-89,195$

"Meet Wand and Wilson-the candidates for ACRL president, ${ }^{,} 883$

"Members assess ACRL prior to the new millennium: re sults of the 1997 member survey, Jenkins, 442-46

"Members running for ALA council: these ACRL members need your vote, "ACRL, 192

"Memorial resolution for Mario Casalini," 582

Menges, Gary, photo., 574

"Miami Book Fair International" poster, 15 th ed., Long. (cover, no. 10)

Michener, Jámes $\mathbf{\Lambda}$., port., 39

Miglio, Daniel, photo., 295

Miller, William, photos., 562, 584, 869; "Provosts, libraries, and electronic information: repons from $\mathrm{AAHF}$ and CNI," 420-22

Mills, Emmy, retired, 461

"Minority librarianship recruitment program launched," 405-6

Minority student success: librarians as partners, "Holmes, 496-98

Miriam Dudley Instruction Librarian Award, 1998, 278 79, 1999,589

Moberly, Heather K., "Nutrition and vegetarianism: sites to really sink your teeth into" \& logos, 265-68

Monsma, Marvin E., retired \& port., 541

Montavon, Victoria, photos., 584, 869

"Monthly Catalog of United States Government Publications (MOCAT)" \& logo, rev. of, 288-89

"More libraries choose Endeavor," 753

Morris, Dilys E., "ISU's Dilys Morris Lazerow Fellowship," 276-77

Morris, Tanga, port., 876

Morrison, Toni, port., 486

Mountainsicle Puh. Co., Miriam Dudley Instruction Librarian Award, 1998, 278-79, 1999, 589

Mullenmeister. Juliet, photo., 278

Munoff, Gerald, appt., 798-99

Muroi, Linda, plootos., 584, 586, 869

\section{$\mathbf{N}$}

Napp, John, "Environmental engineering: protecting health and nacure" \& logos, 834-37, 842

"NARA Archival information locator (NAIL)," rev. of, 202

"NASULGC's 110th annual meeting examines library concerns: copyright, scholarly publishing, and technology discussed," Fatzer, 100-101, 113

NCES, "Academic libraries: 1994 now available from NCES, 334

"NCES releases statistics," 831

"National Digital Library competition," LC, 617

"National Information Literacy Institute," ACRL, 6, 8

NSF, "LC sponsors NSF's Digital Libraries Initiarive-phase $2,{ }^{n} 336$

National Women's History Project, "New materials ready for Women's History Month" \& poster, 6

Neal, James G., ARL president, "Digital copyright legislation pending: an open letter to the library community," 76; news note \& port. 123

Neely, Teresa Y., "Research does happen at conferences," letter to the ed. 152-53

"Neither Pandora nor Cassandra: library services and distance education in the next decade," McManus, 432-35

Nelson, Marilyn, "A cultural awakening: the Harlem Renaissance revisited" \& photo., 656

Nelson, William N., "Are you qualified to serve on the accreditation team? Survey results of six accrediting agencies," 269-72, comment, 436
"NetMeeting: a new and inexpensive alternative for delivering library instruction to distance stuclents," Pival, $758-60$

"New in the AI.A Archives" \& photo., Cardman. 751

"New learning environments: the imporance of information literacy in academiat," Rader, 509-10

"New materials ready for Women's History Month" \& poster, National Women's History Project, 6

New Mexico, "Estacado Library Information Network formed," 405

"New publications," Eherhart, 36-37, 119-20 (\& photo.) 203-4 (\& photo.), 291-92 (\& photo.), 374-75 (\& photo.), 454-55 (\& photo.) 530-33, 613-14 (\& photo.). 711-13 (\& photo.), 792-994 (\& photos.), 892

"New Web journal seeks submissions," Initiaties, 334

Newhouse, Gary, photo., 277

Newman, John, "Academic librarians as scholars: publishing is your moral obligation," 19-20, comments, $152-53$

"News from the field," Davis, 5-10, 73-75, 149-51, 241$47,333-36,405-7,485-88,565-67,653-56,749-53$ $829-32$

"News from the University Libraries Section," Terl talar, 572-73

"NewsTrawler" \& logo, rev. of, 611-12

"The Next Generation Internet: government policy and the future of the Internet," Weingarten, 253-58

Nichol. Thomas, rev, (Douglass: archives of American public address"), 117-18

Nicholls State U., "Cajun/Zycleco Music and Dance Exhibit" poster, (cover, no. 9)

Nielsen, Kristin, "A world in motion," 681-85

Nijhoff International West European Specialist Study Grant, 1999,589

Nim, Myrtle, retired, 380

Nims, Julia K., "How successfully do users search the Weh? One real-time site allows you to 'spy' on searchers," 155-58; "Tips for successful Web searching," 157

"El Niño: facts, figures, images, and predictions" \& logos, Mariner, 663-67

Nixon, Arne, (cover, no. 1)

"No food, no drinks" \& posters, Bancroft, 330, 335

"NCSU libraries opens Scholarly Communication Center," 244

"NCSU wins PR award," 24445

Nova Southeastern U. "NetMeeting: a new and inexpensive alternative for delivering library instruction to distance students," 758-60

"November I deadline for AC.RL poster sessions," 655

Nurick, Aaron, photo., 377

"Nutrition and vegetarianism: sites to really sink your teeth into" \& logos, Moberly, 265-68

Nutry, Iavid J. "Renovating for technology: partnership: produce quick results: how a little team work went a long way" \& photo., 414-16

$\mathbf{0}$

Oakıon Community Coll., "Fradkin and Oakton Community College receive Community College awards" \& photo., 277

Oberly (Eunice Rockwell) Award, 1999, 589

Oberman, Cerise, "The Information Literacy IQ (Institutional Quotient) Test," 348-49; "The Institute for In formation Literacy: formal training is a critical need," 703-5; "Integrating information literacy into the curriculum: how is your library measuring up?," 347, 352

Ocean View Amusement Park, photo., 653

"OCLC and whN begin merger talks," 829

"Oct. 15 deadline for ACRL scholarships," 566

"Oct. 16 deadline for contest to name Choice Web service," 566-67

Odato, Karen, "Keeping current, keeping sane! A Weh tutorial for coping with information overload" \& photo., $248-49$

O'Donnell, James J., "The President's program: O'Donnell and Whearley-dynamic speakers you shouldn't miss," 838 
Ohr-Campbell, T., cartoons, 74, 83, 245, 406, 566, 655, 831

Old Dominion U., "Dedicates new room" \& photo., 149 50; "Special Collections reopens" \& photo., 653

Olsen, Jan Kennedy, appt. \& port., 42

1930 homecoming program, U. of Ill, (cover, no. 8)

"1999 ACRL vice-president/president-clect candidates announced," $486-87$

"Only change is constint: three librarians consider what their jobs will be like in five years" \& ports., Spalding, 601-3

"Order Annual Conference audiocassettes," ACRL, 574

Ortego, Gilda Baeza, appt., 799

Ortiz, Daniel, appt., 717

"Outcomes assessment task force recommendations and resolution," 5834

Owen, Linda, news note, 296

Pacheco, Manuel, photo., 599

"Participate in CLS 'Dynamic Staff swap-n-shop," ACRL, 333-34

Paster, Amy L., "Nutrition and vegetarianism: sites to really sink your teeth into" \& logos, $265-68$

Patterson, Robert H., retired \& port., 298-99

Paynter, Robin, "A workl in motion: refugees and resources" \& logos, 591-94

Pedersoli, Heleni, photo., 678

"Pennsylvania Avenue from U.S. Treasury, Washington, D.C." (cover, no. 5)

Penn. State U., Harrisburg, "Ground broken for Penn State Harrishurg library" \& photo., 488

"Preople in the News," Young, 41-44, 123-26, 209-11, 296$99,378-81,459-62,538-41,618-21,716-19,798-801$, $896-98$

"Performance measurement in libraries and information services: a report from the second Northumbria International Conference," Lakos, 250-51

Peters, Paul Evan, news note, 123

Pfeiffer, Carol, photos., 584, 586, 869

Phillips, Susan, news note, 618

Pilachowski, David M., appt., 799

Pival, Paul R., "NetMeeting: a new and inexpensive alternative for delivering library instruction to distance students," 758-60; rev. ("The Whyfiles" \& logo), 34-35

"Plans for ACRL," Fatzer \& Hardesty, 103-7

"Policy.com" \& logo, rev. of, 612

Ponella, Philip, news note, 459

Poon, Wei Chi, news note, 618

Potter, Ernestine, news note, 798

Potter, William Gray, news note \& port., 896

Pourciau, Lester J. "Crimea '98: libraries and associations in the transient world" \& photo., 596, 603; "The International BOBCATSSS Symposium: shaping the knowtedge society," 273,285

Povsic, Frances, decealsed \& port, 462

"Presenters sought for ACRL's 9th National Conference," 75; ACRL, National Conference, 1999, 5

"Preservation news," Hedherg, 32, 116 (correction, 373), $199,286,368,373,450,527,609,708,788,888$

"The President's program: ODonnell and Wheatley-dynamic speakers you shouldn't miss," Sullivan, 838

"Presickent's Program videos available" 1998, ACRL, 830-31

Primary Source Media, "Thomson mergers form Gale Group," 750

Princeton U., "ISTOR establishes journal conversion facility at Princeton," 75

Pronevitz, Greg, appt., 539

Provine, Rick E., "From audiovisual to media resources," 358

"Provosis, libraries, and electronic information: reports from AAHE and CNI," Jenkins, 420-22

\section{$\mathbf{Q}$}

"QB online: how an old-fashioned question board went electronic" \& photos. Ma, 772-74

Quist, Ned, news note, 459
Rader, Hannelore B., "At the crossroads of information and culture: the 64th IFLA Conference" $\&$ photo, 68687; "Information literacy: the professional issue: sulsjects addressed at the Third National Australian Conference," 171-72; "New learning environments: the importince of information literacy in academia," 509-10

Ransley, Martha, retired, 461

"Rare book librarians prepare for the 19th century," Brown, $570-71$

Rare Books and Manuscripts Librarianship Award, 1999, 589

"RBMS seeks papers for 1999 preconference," 487

Ray, Carole, news note, 618

Reavie, Keir, news note, 618

Rebaza, Claudia, "When is a citation just a frustration? Librarians must stand up for the patron," 512-13

"Reclaiming the Everglades," photo., Brown, 895

"Recruiting the minority librarian: the secret to increasing the numbers," Robles, 779-80

"Register by Jan. 18 and save money!" ACRL, National Conference, 1999, 829

"Register early and save!" ACRL, National Conference, 1999 750

"Register for leadership institute," ACRL, 153

Reichel, Mary, 584, correction, 851

Reiswig, Jennifer, "Introducing clatabase advisor: a new service that will make your research easier" \& photos., 409-12

"Renovating for technology: partnerships produce quick results: how a little team work went a long way" \& photo., Nutty, 414-16

Research Bank Web-Business School Edition, "Thomson Financial Services focuses on academic market," 832

"Research does happen at conferences," Neely, letter to the ed., 152-53

"Resolution honoring Joseph A. Boissé on his retirement," ACRL, 586

"Resources, roles, and active learning covered in three new ACRL publications" \& photo., 407

"Restructuring academic libraries available" \& photo. ACRL, 247

Retirements, 44, 126, 210-11, 298-99, 380-81, 461-62, 541, $620-21,719,801,898$

"Revising the bylaws," ACRL, 109

Rich, Linda, "How successfully do users search the Web? One real-time site allows you to 'spy' on searchers," 155-58; "Tips for successful Web searching," 157

Richardson, John V., Jr., news note, 378

Richardson, Taleia, photo., 278

Rinaldo, Constance, "Keeping current, keeping sane! A Wels tutorial for coping with information overload" \& photo., 248-49

Robbins, Rachel, news note, 618

Robison, Carolyn L., retired, 898

Robison, Dennis E., retired \& port., 44

Rob], Gregory, photo. 9

Robles, Patricia, "Recruiting the minority librarian: the secret to increasing the numbers, $779-80$

Rockwood, Irving, port., 877

"Rodeo Parade: in the Montana-Wyoming Dude Ranch Country" poster, Brewer, (cover, no. 7)

Rogers, Earl, retired, 380-81

Rowley, Gordon, news note, 123

RSC, "Europeans join efforts to expand competition in journal pulslishing," 829-30

Rudner, Judy, appt. \& port., 619

Ryan, John R., port., 830

St. Clair, Gloriana, appt. \& port., 459-60

"St. John's University Law Library joins U.N. Network," 149

Samuel Lazerow Fellowship, 1998, 276-77; 1999, 589

"San Diego Mesa College dedicates new LRC" \& photo., 485 
Saur (K. G.) Award for Best College $E$ Research Libraries Article, 1998, 276; 1999, 589

Saye, Jerry D., news note, 716

Schad, Jasper G., retired \& port., 621

Schmidi, C. James, "Kranich, Schmidt to compete for ALA presidency, " 830

SPARC, "ACRL endorses SPARC program," 565; "Europeans join efforts to expand competition in journal publishing," 829-30

Senecal, Kristin, news note, 716

Senior, Heidi, rev. ("News'Trawler" \& logo), 611-12

Shair, Sondra, retired, 44

Shanton, Kristina, news note, 459

Sharma, R. N., "American librarians visit Gaza strip: their libraries are improving, but they still have a long way to go" \& photo., 27-28

Shaw, William M., Jr., news note, 41

Sheridan, John, photo., 584, 869

Sherrer, Johannah J, deceased, 801

Shontz, Priscilla K., "Tips for new librarians: what to know in the first year of a tenure-track position," 85-88

"Shop for out-of-print books on the Web," 832

Shorb, Stephen R., appt., 539

"Siena College begins building new library" \& photo., 565-66

Silverman, Evelyn, news note, 123

Simoneaux, Laverne, "Provosts, libraries, and electronic information: reports from AAHE and CNI, 420-22

Simonis, James J., news note \& port., 209

Smith, Marion McGill, deceased \& port., 381

Snelson, Pamela, appt. \& port., 539-40

Society of Cincinnati, "The manner in which the American Colonies Declared Themselves Independant of the King of England...July 4, 1776," (cover, no. 6)

"Society of Cincinnati Library reopens" \& photo., 406

So. Methodist Coll., Leab Award \& photo., 279-80

"SMU breaks ground for new library expansion." 245-46

Sozansky, Bill, photo., 749

Spalding, Helen $\mathbf{H}$., "Only change is constant: three librarians consider what their jobs will be like in five years" \& port., 601-2; photos., 584, 586, 869

Spang, Lothar, photo., 278

"Special Collections reopens at Old Dominion University" \& photo., 653

Springer-Verlag, "EBSCO and Springer Verlag partner to provide journals online, " $653-54$

Stalker, Laura, photo., 574

"Stanford, UC-Berkeley, and UT-Austin form Latin American cooperative," 241

Stanford U., "Libraries in operation after flood" \& photo. 241-43; "Stanford, UC-Berkeley, and UT-Austin form Latin American cooperative," 241

"Stay home from conferences and do research," Willson, letter to the ed., 152

Stewart, James, news note, 618

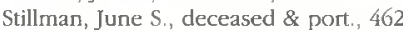

Sullivan, Maureen, "Leadership through the lens of learning: a look at the role of the librarian for the new century" \& port., 673-74; "Message from the vice-president" \& port., 856-57; photos., 584, 586 , 869; port., 437; "The President's program: O'Donnell and Wheatley-dynamic speakers you shouldn't miss," 838

Summers, Ed, "Gateways to social work/welfare on the net: practice wisclom to go" \& logos, 163-67

"Support the Digital Copyright Act," 115

Sutton, Margot, "Focus on the invited papers program exciting programs to attend at National Conference" \& photos., 597-600;port., 877

Sweat, Mary Lee, photo, 586

"Switchboard," rev. of \& logo, 202

Tantco-Stauder, Dolores, retired \& port., 211
"Teaching undergrads WEB evaluation: a guide for library instruction," Kapoun, 522-23

Tease, Joan, "The Mansfield protocol for laptop computer circulation: how a library can provide its own technical support" \& photo., 507-508, comment, 763

"Technology exhibits at ALA: a look at what's new" \& photos., DePellegrin, 577-80

"Ten things you can do to go global," 79

TerHaar, Linda K., "News from the University Libraries Section," 572-73

"Texan Digital Library Alliance formed," 5-6

Texas, "Texan Digital Library Alliance formed," 5-6

Tex. State Lib. and Archives Commisssion, "Texan Digital Library Alliance formed, ${ }^{n}$ 5-6

Tex. Tech U., clarification, 247

"Texas Tech dedicates new library," photo., 73

"Texas Tech joins ARL," 73

Thompson, Hugh, port., 877

Thomson Business Information (TBI), "... and the Thomson Science and Technology Group," 750; "Mergers form Gale Group," 750

"Thomson Financial Services focuses on academic market, " 832

"Thomson mergers form Gale Group," 750

Thomson Science and Technology (TST), "... and the Thomson Science and Technology Group," 750

Thresher, Joyce, photo., 508

Tichenor, Irene, appt, 297

Tiger Stadium, photo., 2

"The time to lead: ACRL seeks nominees for office," ACRL, $284-85$

"Tips for new librarians: what to know in the first year of a tenure-track position," Shontz, 8588

"Tips for successful Web searching," Nims, 157

"Tobacco Control Archives" \& logo, rev. of, 529

Toomer, Clarence, appt., 897

Topper, Elisa, "Leaves ACRL," 407

Tozer, Kristen, rev. ("Life Magazine Home Page" \& logo), 288

Trejo, Ninfa, "Creating the developmental teaching portfolio: a great tool for self-assessment" \& illus., 776-78

"The Tribal Library Project: interns, American Indians, and library services: a look at the challenges, "Biggs, 25962

Tribit, Donald K., retired, 126

Tudiver, Lillian, "Faith in librarians restored by Branch's praise of reading," letter to the ed, 153

Tuñón, Johanna, "NetMeeting: a new and inexpensive alternative for delivering library instruction to clistance students," 758-60

Turock, Betty, news note, 296

Tuttle, Marcia, news note \& port., 296

Twain, Mark, port., 486

"Two state systems subscribe to ACS Web journals," 653

$\mathbf{u}$

Ugorji, Lucinda, photo., 501

"Uncle Sam," rev. of, 34

United Kingdom, "JSTOR usage rises 363 percent and establishes a UK site, ${ }^{\text {" } 334, ~} 336$

U.N., "St. John's University Law Library joins U.N. Network," 149

U.S. Naval Academy, "Ceremony commemorating the 25th Anniversary" \& photo., 830

"UMI adds Univ, of Chicago dissertations," 151

"Univ. of Maryland contracts for security study," 243-44

U. of Ariz., "Creating the developmental teaching portfolio: a great tool for self-assessment ${ }^{\prime \prime} \&$ illus., $776-78$; Leah Award \& photo., 279-80; "Living the future II organizational changes for success," 494-95; "Living the Future II in Arizona," 74

UC, "Two state systems subscribe to ACS Web joumals," 653

UC, Berkeley, "Stanford, UC-Berkeley, and UT-Austin form Latin American cooperative," 241

"UCLA and Getty offer summer institute," 832

"UCLA Senior Fellow applications due," 832 
UC, San Diego, "Introducing database advisor: a new service that will make your research easier" \& photos., 409-12

UC, Santa Cruz, "Dedicated UC-Santa Cruz librarians continue to give," 831

U. of Central Ark., "Minority student success: librarians as partners, "496-98

U. of Chicago, "UMI adds Univ. of Chicago dissertations," 151

U. of Colo., "Catalog on the Web" \& logo, 149; "Nobel Prize winner Tom Cech and the Colorado Science Library staff" photo., 9

U. of Ill., "New in the ALA Archives" \& photo., 751; 1930 homecoming program, (cover, no. 8)

U. of IIl., U-C, "QB online: how an old-fashioned question board went electronic" \& photos., 772-74

"Univ, of Illinois breaks ground" \& photo., 753

"University of Kentucky dedicates new library" \& photo., 405

U. of Louisville, "Cafe in Ekstrom Library Lobby" \& photo., 5

U. of Miami, Everglades collection, photo., 826

U. of Pittsburgh, "Minority librarianship recruitment program launched," 405-6

U. of R.I., "Do's and don'ts for moving a small academic library: fourteen helpful tips" \& photos., 499-503

"Univ. of Southern Maine renames library for donors" \& photo., 8

U. of Tenn, Chattanooga, "Making federal work-study work: four steps that one library uses to hire students" \& photos., 490-92, 525

U. of Tex., Austin, "Stanford, UC-Berkeley, and UT-Austin form Iatin American cooperative, "241

U. of Vermont, "A cultural awakening: the Harlem Renaissance revisited" \& photo., 656

U. of Western Ontario, "King's College Library wins award" \& photo., 150-51

U. of Wis., "More libraries choose Endeavor," 753; "Two state systems subscribe to ACS Web journals," 653

Valentine, Barbara, rev. ("The Library of Congress country studies" \& logo), 117

"A value that bonds: the library as a uniquely democratic institution," Collins, 355-56

Values for the electronic information age ("The axe for the frozen sea ...'" 16, 35, comment, 153; "Crossroads of a profession," 504-5; "Defending the freedom to read," 169-70; "A diminished thing," 263-64; "A value that bonds," 355-56)

Varner, Carroll, appt. \& port., 717

Veaner, Allen B., 239 (port., cover, no. 4); "Named Aca demic/Research Librarian of the Year" \& port., 275

"Virtual bookstores," 660

"Volcano World," rev. of, 528-29

\section{$\mathbf{w}, \mathbf{x}$}

Wagner, Robin, appt. \& port., 799

Wake Forest U., "More libraries choose Endeavor," 753

Walker, Stephen, "When systems fail: does your library have a back-up plan?," 83-84

Wand, Patricia Ann, port., 844

Warro, Edward A., appt., 717

Wash. and Lee U., bookplates, 334 (2)

"Washington hotline," Bradley, 30, 115, 366, 449, 524-25, 607, 707, 786, 886; Weingarten, 197, 211, 253-58

Wash. State, Community and Technical College system, "More libraries choose Endeavor," 753

Watson-Boone, Rebecca, Constancy and change in the worklife of research university librarians \& photo., 752

Waugh, Kappa, cartoons, 8, 151, 336, 488, 752, 759; illustrations, 776-77

The way I see it "Academic librarians as scholars," Newman, 19-20, comments, 152-53; "Don't lead a road warrior existence," Farmer, 784-85; "Making collections work," Hazen, 97-99, 113; "Neither Pandora nor Cassandra," McManus, 432-35; "Only change is constant" \& ports., Spalding, 601-3; "Recruiting the minority librarian," Robles, 779-80; "When is a citation just a frustration?" Rebaza, 51213

Wayne State U., photo., 849; "Program wins IS Innovation Award" \& photo., 278

"Web rings: an alternative to search engines," Casey, 761-63

Wedgeworth, Robert, retired \& port., 541

Weible, Arlene, rev. ("Justice information center" \& logo), 709

Weingarten, Rick, "The Next Generation Internet: government policy and the future of the Internet," 253-58; "Washington hotline," 197, 211, 253-58

Wells, Amy Tracy, rev. ("Foundation Center"), 371

Wellstone, Paul, photo., 749

"Western Governors University offers virtual tours of campus," 487

Wheatley, Margarer J., "The President's program: O'Donnell and Wheatley-dynamic speakers you shouldn't miss," 838

"When is a citation just a frustration? Librarians must stand up for the patron," Rebaza, 512-13

"When systems fail: does your library have a back-up plan?" Walker, 83-84

Whiting, Francis Brooke, deceased, 801

"The Whyfiles" \& logo, rev. of, 34-35

Wilhelm, Cara, "HealthWeb: an Internet collaboration" \& photos., $338-40$

Williamson, Jeanine M. "ACRL's Doctoral Dissertation Award," 460

Willson, David A., "Stay home from conferences and do research," letter to the ed., 152

Wilson, Betsy, "Information literacy: best practices and models," 351-52; "The Information Literacy IQ (Institutional Quotient) Test," 348-49; "Integrating information literacy into the curriculum: how is your library measuring up?," 347, 352; news note, 716; port. 844

Wilson, Blenda J., photos., 599, 753

Wilson, Jennifer, appr., 42

Wilson, Myoung Chung, "Information provision: an international seminar on politics and strategy, "604-6

Wilson, Pam, photo., 9

Wilson, Pat, deceased, 621

Wingfield, Tommie, news note, 618

Wittman, Sandra, photo., 277

WLN, "OCLC and WLN begin merger talks," 829

Wood, Don E., retired \& port., 461-62

The wondlands in winter (watercolor), Kennedy, (cover, no. 11)

Wor-Wic Community Coll., "Creation of a Wels list for clinical disciplines: a step-by-step account of the 'Webliography' process" \& photo., 768-70

"A world in motion: refugees and resources" \& logos, Paynter, 591-94

Wright, Cathie, photo., 753

Wright, Joyce, "QB online: how an old-fashioned question board went electronic" \& photos, , 772-74

$\mathbf{Y}$

Yagodich, William "Bill", deceased, 44

Young, Ann-Christe, "Grants and acquisitions," 38-39, $121-22,206-7,294-95,376-77,456-57,535-36,616-$ $17,714-15,795-96,894$; "People in the news," $41-$ $44,123-26,209-11,296-99,378-81 ; 459-62,538-$ 41, 618-21, 716-19, 798-801, 896-98; port, 877

Young, Sherry E. "Making federal work-study work: four steps that one library uses to hire students" \& photos., $490-92,525$

"Your comments wanted," 361

$\mathbf{z}$

Zambella, BethAnn, "Living the future II: organizational changes for success," 494-95

Zne, Lucinda R., revs. ("American Directory Assistance" \& logo, 201; "Switchboard" \& logo, 202) 